\title{
Organophosphorus and carbamates residues in milk and feedstuff supplied to dairy cattle ${ }^{1}$
}

\author{
Rafael Fagnani ${ }^{2 *}$, Vanerli Beloti ${ }^{2}$, Ana Paula P. Battaglini² ${ }^{2}$ Karen da S. Dunga ${ }^{2}$ \\ and Ronaldo Tamanini ${ }^{2}$
}

\begin{abstract}
Fagnani R., Beloti V., Battaglini A.P.P., Dunga K.S. \& Tamanini R. 2011. Organophosphorus and carbamates residues in milk and feedstuff supplied to dairy cattle. Pesquisa Veterinária Brasileira 31(7):598-602. Laboratório de Inspeção de Produtos de Origem Animal, Departamento de Medicina Veterinária Preventiva, Centro de Ciências Agrárias, Universidade Estadual de Londrina, Rodovia PR 445 Km 380, Cx. Postal 6001, Londrina, PR 86051-980, Brazil. E-mail: rafaelfagnani@hotmail.com

Considering acute and chronic toxicity effects on human and animal health caused by pesticide residues in food, this study aimed to analyze organophosphorate (OP) and carbamate (CB) in feedstuff and water destined for dairy cattle, as well as in the milk produced by these animals, through gas chromatography (GC). In the Agreste region of Pernambuco, Brazil, 30 raw milk samples and all components of the animals' diet were collected from several farms. Out of the 30 milk of milk analyzed, six (20\%) were contaminated with OP, five (16.7\%) with CB, and one sample with both pesticides. From 48 analyzed feed samples, 15 (31.25\%) were contaminated with residues of $\mathrm{OP}$, six $(12.50 \%)$ with $\mathrm{CB}$, and one sample was contaminated with both pesticides. Out of 16 water samples analyzed, six $(37.50 \%)$ were contaminated with OP residues, but non with CB. In four dairy farms the pesticides detected in milk were compatible with the active principles found in water and/or foodstuff, suggesting them to be the source of contamination.
\end{abstract}

INDEX TERMS: Pesticides, gas chromatography, Brazil, Pernambuco, contamination.

RESUMO.- [Resíduos de praguicidas organofosforados e carbamatos em leite e alimentação animal de propriedades leiteiras.] Considerando os efeitos tóxicos, agudos e crônicos, para a saúde humana e animal, causados por resíduos de praguicidas em alimentos, este trabalho teve como objetivo a identificação e quantificação por cromatografia gasosa (CG) de resíduos de praguicidas organofosforados (OF) e carbamatos (CB) no leite cru, nos componentes da alimentação e água dos animais. Foram coletadas 30 amostras de leite cru da região agreste de Pernambuco e ao mesmo tempo eram coletadas amostras de alimentação e água ofertada aos animais em lactação de cada propriedade, totalizando 109 amostras de alimentação e 38 amostras de água. Das 30 amostras de leite analisadas, seis (20\%) estavam contaminadas por resíduos de OF, cinco (16,7\%) por resíduos de CB e uma amostra por ambos os praguicidas. Das 109 amostras de alimen-

\footnotetext{
${ }^{1}$ Received on September 9, 2010.

Accepted for publication on March 25, 2011.

${ }^{2}$ Laboratório de Inspeção de Produtos de Origem Animal (LIPOA), Departamento de Medicina Veterinária Preventiva, Centro de Ciências Agrárias, Universidade Estadual de Londrina, Rodovia Celso Garcia Cid PR 445 Km 380, Campus Universitário, Cx. Postal 6001, Londrina, PR 86051-980, Brazil. *Corresponding author: rafaelfagnani@hotmail.com
}

tação ofertada aos animais coletadas, 48 foram analisadas, com 15 amostras $(31,25 \%)$ apresentando resíduos de OF, seis amostras (12,50\%) contaminadas por resíduos de CB e uma amostra positiva para ambos os praguicidas. Das 16 amostras de água analizadas, seis $(37,50 \%)$ estavam contaminadas por resíduos de OF e nenhuma apresentou resíduos de CB. Em quatro propriedades leiteiras os praguicidas detectados no leite foram compatíveis com o princípio ativo detectado na alimentação e/ou na água ofertada aos animais, sugerindo uma possível fonte de contaminação, mas não a única.

TERMOS DE INDEXAÇÃO: Praguicidas, cromatografia gasosa, Pernambuco, Brasil, contaminação.

\section{INTRODUCTION}

Organophosphorus (OP) and carbamates (CB) are widely used to control plagues in plantations. The inappropriate use of these substances may leave residues in feed supplied to cattle and these, when metabolized, are deposited in fat and muscles, and might also be found in milk. Similarly, the direct use of these substances to control parasites in cattle might also cause residues in milk when the withdrawal period is not respected (Rothwell et al. 2001). 
Most of the time, the presence of pesticide residues in animal feeds is the main source of pesticide contamination of dairy products, but other factors may include environmental contamination, application of pesticides on farm animals for ectoparasite removal and accidental spills (Tsiplakou et al. 2010).

The occurrence of pesticides residues in milk and dairy products is a matter of public health concern, since they are widely consumed by infants, children and adults throughout the world. Pesticides monitory studies are useful to know the level and the main sources of milk and dairy product contamination, and the more research on this subject, the more reliable are the data generated. Furthermore, these data can be used for prevention and control of chemical contaminants in milk and dairy products (Jahed Khaniki 2007).

In view of this and considering acute and chronic toxicity effects on human and animal health caused by pesticide residues in food, this study aimed to analyze the presence of $\mathrm{OP}$ and $\mathrm{CB}$ in feedstuffs and water destined for dairy cattle, as well as in the milk produced in the Agreste region of Pernambuco, Brazil.

\section{MATERIALS AND METHODS}

\section{Sampling}

From 28 dairy farms and two community milk coolers, 30 milk samples (one from each farm or milk cooler) were collected in August 2007. At the same time, all components of the animal diet from each farm were also collected, totalizing 109 samples of animal feed (roughage, pasture, concentrated and minerals) and 38 samples of water supplied to dairy cattle (sometimes with two or more sources in the same farm).

All the samples were placed in plastic bags and transported in styrofoam boxes with recyclable ice and stored at $-20^{\circ} \mathrm{C}$ until processing. The collection of concentrated food samples was conducted in barns where the food were stored, or in grain silos. In the case of concentrated food stored in sacks, random samples from the sacks destined for the next feeding time of the animals were collected.

The raw milk samples were collected directly from the cooling tanks or from cans of the farms. After homogenization, aliquots of $300 \mathrm{ml}$ were removed, placed in bags and maintained frozen $\left(-20^{\circ} \mathrm{C}\right)$ until analysis. Water samples were collected from streams, lakes or dams.

The period between collection and analysis was of 30 days for milk samples and eight months for water and foodstuff samples.

\section{Extraction method}

The sample extraction was carried out according to the method of Pagliuca et al. (1996). Samples was defrosted and performed by extraction and centrifugation of $20 \mathrm{~g}$ or $20 \mathrm{ml}$ sample with $25 \mathrm{ml}$ of a mixture of acetone: acetonitrile (1:4), followed by partition with $50 \mathrm{ml}$ dichloromethane. The collected dichloromethane extracts were evaporated off and reconstituted with $1 \mathrm{ml}$ acetonitrile. Thereafter a clean-up with solid phase extraction was carried out, eluting with $2 \mathrm{ml}$ acetonitrile and $1 \mathrm{ml} 2$-propanol. Finally the sample obtained was concentrated to dryness and redissolved in $200 \mathrm{ml}$ acetone to be injected into the system.

\section{Analytic methodology}

Gas Chromatography (GC) analysis were performed in a Varian 3600 with Auto Sampler 8200, with electron capture detection, using a DB-5 capillary column with $30 \mathrm{~m}$ and $250 \mathrm{~mm}$ diameter and nitrogen as carrier gas, injector and detector temperatures of $250^{\circ} \mathrm{C}$ and $300^{\circ} \mathrm{C}$, respectively. The detection limit was $0.01 \mu \mathrm{g} \mathrm{L} \mathrm{L}^{-1}$ (Moraes 1991, Nunes et al. 1997). The standard used were: Chlorpyrifos, Coumaphos, Diazinon, Dichlorvos, Dimethoate, Disulfoton, Ethion, Fenthion, Phorate, Phosalone, Malathion, Methamidophos, Mevinphos, Meta-systos, Methylparathion, Monocrotophos and Trichlorfon for organophosphorus and Aldicarb, Bendiocarb, Carbaryl, Carbofuran, Carbosulfan, Methomyl, Propoxur and Thiodicarb for carbamates, all from Sigma-Aldrich.

\section{Monitory study}

All 30 raw milk samples were analyzed for pesticides OP and $\mathrm{CB}$, but only feed and water samples from farms where residues were detected in milk were analyzed, tracking the possible sources for milk contamination in the feedstuff destined for animal consumption.

\section{Data analysis}

Descriptive statistics were calculated for each active principle separated by milk, water and feedstuff, using SAEG 9.1 software (SAEG, 2007). The value $0.01 \mu \mathrm{L} \mathrm{L}^{-1}$ was adopted for samples with residues lower than the detection limit.

\section{RESULTS AND DISCUSSION}

Milk

Pesticides were found in the milk from 11 farms and one milk cooler (Fig.1), totalizing 12 positives milk samples. The main pesticide was fenthion, detected in four samples of 12 (33.33\%), followed by dimethoate $(25 \%)$, coumaphos (8.33\%) and malathion (8.33\%). In CB group, the pesticides detected were carbofuran (25\%), aldicarb $(16.67 \%)$ and carbaryl $(8.33 \%)$. In some samples, two or more active principals were detected, what explains percentages over $100 \%$. The frequency of pesticides found in this study is in agreement with Araújo et al. (2000) that noted that the most pesticides commonly used in Pernambuco are from OP class, followed by CB and pyrethroids.

The frequency of samples positive to $\mathrm{OP}$ and $\mathrm{CB}$ residues was lower than the one found by Nero et al. (2007) that verified 196 (93.8\%) positive samples among 209 raw milk samples in four Brazilian regions. The analytic methodology used by Nero et al. (2007) was Thin Layer Chromatography, which would justify the difference in the results, since this technique presents lower specificity when compared with GC (Collins et al. 1997).

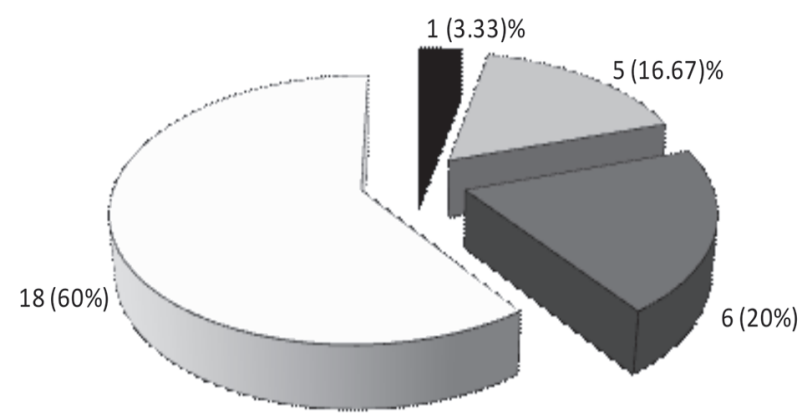

Positive samples for $O P$ and $C B$

$\square$ Positive samples for CB

Positive samples for OP

$\square$ Samples without residues detection

Fig.1. Organophosphorus (OP) and Carbamates (CB) residues frequency in 30 raw milk samples collected from 28 farms and 2 community milk coolers in Pernambuco, August, 2007. 


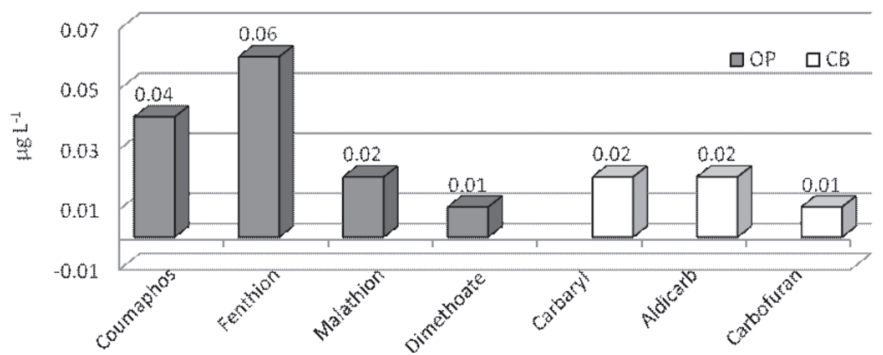

Fig 2. Contamination averages in ìg $\mathrm{L}^{-1}$ from each pesticide's active principle detected in raw milk samples $(n=30)$ collected in Pernambuco, August 2007, separated by chemical group: organophosphorus (OP) and carbamates (CB).

Table 1. Mean concentration $\left(\mu \mathrm{g} \mathrm{L}^{-1}\right)$, standard deviation and range $\left(\mu \mathrm{g} \mathrm{L}^{-1}\right)$ of pesticides in the milk, feed and water samples from dairy farms in Pernambuco, August 2007

\begin{tabular}{lccc}
\hline \multirow{2}{*}{ Coumaphos } & $\begin{array}{c}\text { Milk } \\
\left(\mathrm{n}=30 / \mathrm{n}^{\prime}=12\right)\end{array}$ & $\begin{array}{c}\text { Feed } \\
\left(\mathrm{n}=48 / \mathrm{n}^{\prime}=22\right)\end{array}$ & $\begin{array}{c}\text { Water } \\
\left(\mathrm{n}=16 / \mathrm{n}^{\prime}=6\right)\end{array}$ \\
\cline { 2 - 4 } Fenthion & $0.04 / 0.16$ & Mean $/ \mathrm{SD}(\mathrm{range})$ & $\mathrm{n} . \mathrm{d}$ \\
& $(0.01-0.87)$ & & \\
Malathion & $0.06 / 0.13$ & $0.95 / 2.21$ & $0.06 / 0.12$ \\
& $(0.01-0.05)$ & $(0.01-8.11)$ & $(0.01-0.43)$ \\
Dimethoate & $0.02 / 0.03$ & $80.45 / 363.14$ & $0.78 / 3.04$ \\
& $(0.01-0.20)$ & $(0.01-1782.85)$ & $(0.01-12.02)$ \\
Metil-parathion & $0.01 / 0.02$ & $0.01 / 0.01$ & n.d \\
& $(0.01-0.11)$ & $(0.01-0.07)$ & \\
Diazinon & n.d & $1.00 / 3.12$ & $0.13 \pm 0.48$ \\
& $(0.01-12.89)$ & $(0.01-1.93)$ & \\
Carbaryl & n.d & $4.72 / 8.04$ & $0.32 / 0.72$ \\
& $(0.01-27.10)$ & $(0.01-2.81)$ & \\
Aldicarb & $0.02 / 0.06$ & $0.01 / 0.02$ & n.d \\
& $(0.01-0.33)$ & $(0.01-0.12)$ & \\
Carbofuran & $0.02 / 0.04$ & $0.04 / 0.07$ & n.d \\
& $(0.01-0.22)$ & $(0.01-0.26)$ & n.d \\
& $0.01 / 0.01$ & n.d &
\end{tabular}

$\overline{\mathrm{N}}=$ samples analized; $\mathrm{n}^{\prime}=$ samples positives for at least one pesticide; $\mathrm{SD}=$ standard deviation; n.d. $=$ not detected

Figure 2 and Table 1 present the levels of pesticides found in the positive samples. Despite Brazilian law still does not established limits for $\mathrm{OP}$ and $\mathrm{CB}$ pesticides in milk, the residue levels were lower than the Maximum Residues Limit (MRL) fixed by FAO/WHO Codex Alimentarius for Dimethoate, Carbaryl and Carbofuran $\left(50 \mu \mathrm{g} \mathrm{L}^{-1}\right)$, Fenthion and Coumaphos $\left(500 \mu \mathrm{g} \mathrm{L}^{-1}\right)$ and for Aldicarb $\left(10 \mu \mathrm{g} \mathrm{L}^{-1}\right)$ (FAO/ WHO, 2006). For pesticides with no MRL established, as malathion, the limit of the European Commission $\left(10 \mu \mathrm{g} \mathrm{L}^{-1}\right)$ (EEC 2005) was used.

\section{Water and animal feedstuff samples}

Table 1 presents the descriptive statistic for water and feed, while Tables 2 and 3 show the analyzed feedstuff for OP and $\mathrm{CB}$, respectively. Among the 48 samples analyzed (20 only for OP, 24 only for CB and 4 for both) 22 (45.83\%) were positive, with 15 (31.25\%) positives samples only for OP, six $(12.50 \%)$ only for CB and one $(2.08 \%)$ for both pesticides. The pesticides averages levels in $\mu \mathrm{g} \mathrm{L}^{-1}$ were 0.01 for dimethoate, 4.72 for diazinon, 80.45 for malathion, 0.95 for fenthion, 1.00 for methylparathion, 0.04 for aldicarb, and 0.01 for carbaryl.
Table 2. Gas cromatograph quantification of organophosphorus pesticides residues by feed animal sample, from dairy farms in Pernambuco, August 2007

\begin{tabular}{|c|c|c|c|c|c|}
\hline \multicolumn{6}{|c|}{ Organophosphorus } \\
\hline $\begin{array}{l}\text { Sample } \\
\text { descrip- } \\
\text { tion }\end{array}$ & $\begin{array}{c}\text { Number } \\
\text { of collec- } \\
\text { ted samples }\end{array}$ & $\begin{array}{l}\text { Number } \\
\text { of samples } \\
\text { analyzed } \\
\text { for OP }\end{array}$ & $\begin{array}{l}\text { Number } \\
\text { of posi- } \\
\text { tive sam- } \\
\text { ples }\end{array}$ & $\begin{array}{c}\text { Active } \\
\text { princi- } \\
\text { ples detec- } \\
\text { ted }\end{array}$ & $\begin{array}{l}\text { Quantifica- } \\
\text { tion } \mu \mathrm{g} \mathrm{L}^{-1}\end{array}$ \\
\hline \multirow[t]{6}{*}{ Cassava } & 2 & 2 & 2 & Dimethoate & 0.07 \\
\hline & & & & Diazinon & 1.67 \\
\hline & & & & & 3.98 \\
\hline & & & & Methylparathion & n 2.20 \\
\hline & & & & Malathion & 1782.85 \\
\hline & & & & Fenthion & 7.29 \\
\hline \multirow[t]{8}{*}{ Pasture } & 28 & 6 & 5 & Diazinon & 6.17 \\
\hline & & & & & 20.26 \\
\hline & & & & & 6.68 \\
\hline & & & & Methylparathion & n 12.89 \\
\hline & & & & Malathion & 24.24 \\
\hline & & & & & 1.73 \\
\hline & & & & Fenthion & 3.27 \\
\hline & & & & & 1.51 \\
\hline \multirow[t]{4}{*}{ Soy } & 13 & 4 & 2 & Diazinon & 19.39 \\
\hline & & & & & 1.78 \\
\hline & & & & Malathion & 0.35 \\
\hline & & & & Fenthion & 1.36 \\
\hline \multirow[t]{2}{*}{ Corn } & 8 & 2 & 1 & Diazinon & 2.67 \\
\hline & & & & Malathion & 0.28 \\
\hline \multirow{3}{*}{ Cottonseed } & 10 & 2 & 2 & Diazinon & 2.04 \\
\hline & & & & Fenthion & 0.38 \\
\hline & & & & Malathion & 9.60 \\
\hline \multirow[t]{2}{*}{ Salt } & 11 & 2 & 2 & Diazinon & 1.82 \\
\hline & & & & Malathion & 1.50 \\
\hline Poultry & 4 & 1 & 1 & Diazinon & 19.56 \\
\hline \multirow[t]{2}{*}{ Litter } & & & & Malathion & 93.91 \\
\hline & & & & Fenthion & 0.76 \\
\hline \multirow[t]{5}{*}{ Barley } & 2 & 1 & 1 & Dimethoate & 0.02 \\
\hline & & & & Diazinon & 27.10 \\
\hline & & & & Methylparathion & n 8.75 \\
\hline & & & & Malathion & 16.08 \\
\hline & & & & Fenthion & 8.11 \\
\hline $\begin{array}{l}\text { Other feed } \\
\text { itens }\end{array}$ & 31 & 4 & 0 & - & n.d \\
\hline TOTAL & 109 & 24 & 16 & - & - \\
\hline
\end{tabular}

n.d $=$ not detected.

Table 3. Gas chromatography quantification of carbamates pesticides residues by feed animal sample, from dairy farms in Pernambuco, August 2007

\begin{tabular}{|c|c|c|c|c|c|}
\hline \multicolumn{6}{|c|}{ Carbamates } \\
\hline $\begin{array}{c}\text { Sample } \\
\text { description }\end{array}$ & $\begin{array}{c}\text { Number } \\
\text { of collec- } \\
\text { ted samples }\end{array}$ & $\begin{array}{c}\text { Number } \\
\text { of samples } \\
\text { analyzed } \\
\text { for CB }\end{array}$ & $\begin{array}{c}\text { Number } \\
\text { of positi- } \\
\text { ve samples }\end{array}$ & $\begin{array}{c}\text { Active } \\
\text { principles } \\
\text { detected }\end{array}$ & $\begin{array}{c}\text { Quantifi- } \\
\text { cation } \\
\mu \mathrm{g} \mathrm{L}^{-1}\end{array}$ \\
\hline \multirow[t]{2}{*}{ Pasture } & 28 & 5 & 2 & Aldicarb & 0.10 \\
\hline & & & & Carbaryl & 0.12 \\
\hline \multirow[t]{2}{*}{ Corn } & 8 & 3 & 2 & Aldicarb & 0.24 \\
\hline & & & & & 0.16 \\
\hline \multirow[t]{2}{*}{ Cottonseed } & 10 & 4 & 2 & Aldicarb & 0.10 \\
\hline & & & & & 0.05 \\
\hline Poultry Litter & 4 & 1 & 1 & Aldicarb & 0.26 \\
\hline $\begin{array}{c}\text { Other feed } \\
\text { items }\end{array}$ & 59 & 15 & 0 & - & n.d \\
\hline TOTAL & 109 & 28 & 7 & - & - \\
\hline
\end{tabular}

n.d. $=$ not detected. 
In general, feedstuff samples presented high contamination levels; some with five principles simultaneous, as barley, and some with residues over the limit introduced from the EU-Pesticide residue legislation, as pasture, cassava, soy and barley (>10 $\left.\mathrm{g} \mathrm{L}^{-1}\right)$.

One of the cassava samples presented the highest quantification for malathion, with $1782.85 \mu \mathrm{g} \mathrm{L} \mathrm{L}^{-1}$. The pasture, corn and cottonseed samples also presented a high frequency of contamination by pesticides residues.

One of the poultry litter samples presented three OP principles simultaneously, with high quantification levels. The use of poultry litter in ruminant feed was forbidden in Brazil in 2001 as one of the most important sanitary issues of Agriculture Ministry in Brazil to prevent Bovine Spongiform Encephalopathy (Brasil 2001). Other inconvenient are pointed by the use of poultry litter in ruminant feed, as the presence of ectoparasiticides residues used in aviculture and termiticides residues used on wood, whose sawdust is used as litter component (Ortolani \& Brito 2001). These residues are persistent and can be transferred to animal products when litter is provided in feed. Although the use and commercialization are forbidden, six of the 28 farms were offering poultry litter to dairy cattle feed.

Among the 11 farms where milk was contaminated by $\mathrm{OP}$ and/or CB residues, in only two were not detected these pesticides residues in water and feed animal samples, pointing the occurrence of pesticides contamination in products destined to animals feed, showing the necessity of toxicologic control on them.

Out of 38 water samples collected, 16 samples were analyzed, from milk farms where residues were detected in milk, six (37.50\%) presented OP residues and there was no $\mathrm{CB}$ residues in any sample. Pesticides detected in water and their levels averages in $\mu \mathrm{g} \mathrm{L}^{-1}$ were: 0.32 for Diazinon, 0.78 for Malathion, 0.13 for Methylparathion and 0.06 for Fenthion.

Acid conditions, like presence of some microorganisms and/or organic material, enhance the stability of this group and support their own permanence (Osweiler 1998). This can explain the higher frequency for OP group, as biggest part of water samples were collected from areas filled with clay and dams, where there was large quantity of animal feces and clay. OP and CB pesticides residues in water systems can be hardly detected, as they suffer dilution effects, hydrolysis and photolysis on superficial waters. Still, some researchers found high levels in this ambience (Sankararamakrishnan et al. 2000, García de Llasera \& Bernal-González 2001).

Although exists a national law for use and discard package pesticides, it is common between some Pernambuco farmers leave empty packages or rests of products spread out through field. Rain and irrigation systems can contribute to dragging these residues in land until they achieve streams and reservoirs (Araújo et al. 2000).

\section{Monitoring: residues in milk and residues in feedstuff and water}

The reports on residues in milk with controlled feeding experiments, where a constant amount of pesticide was fed regularly up to a certain duration, are contradictory. Even in
Table 4. Four dairy farms of Pernambuco with the same active principles residues in milk and feedstuff, detected and quantified by gas chromatography, august 2007

\begin{tabular}{|c|c|c|c|c|c|}
\hline Farm & $\begin{array}{c}\text { Residues } \\
\text { detected } \\
\text { in milk }\end{array}$ & $\mu \mathrm{g} \mathrm{L}^{-1}$ & Food & $\begin{array}{l}\text { Detected } \\
\text { residues }\end{array}$ & $\mu \mathrm{g} \mathrm{L}^{-1}$ \\
\hline \multirow[t]{9}{*}{ I } & Dimethoate & 0.01 & Water & n.d. & n.d \\
\hline & Fenthion $^{*}$ & 0.5 & Cottonseed & Aldicarb ${ }^{*}$ & 0.1 \\
\hline & & 0.22 & & Fenthion $^{*}$ & 0.38 \\
\hline & & & & Diazinon & 2.04 \\
\hline & & & Pasture & Diazinon & 20.26 \\
\hline & & & & Methylparathion & 12.89 \\
\hline & & & & Malathion & 24.24 \\
\hline & & & Soy & n.d. & n.d \\
\hline & & & Corn & Aldicarb ${ }^{*}$ & 0.24 \\
\hline \multirow[t]{6}{*}{ II } & Aldicarb* & 0.13 & Water source I & n.d. & n.d \\
\hline & & & Water source II & n.d. & n.d \\
\hline & & & Pasture & n.d. & n.d \\
\hline & & & Corn & Aldicarb ${ }^{*}$ & 0.16 \\
\hline & & & Cottonseed & Aldicarb* & 0.05 \\
\hline & & & Soy & n.d. & n.d \\
\hline \multirow[t]{9}{*}{ III } & Fenthion* & 0.22 & Water & Diazinon & 0.54 \\
\hline & & & & Fenthion ${ }^{*}$ & 0.43 \\
\hline & & & Pasture & Diazinon & 6.68 \\
\hline & & & Cassava & Dimethoate & 0.07 \\
\hline & & & & Diazinon & 1.67 \\
\hline & & & & Methylparathion & 2.20 \\
\hline & & & & Malathion & 1782.85 \\
\hline & & & Soy & n.d. & n.d \\
\hline & & & Mineral salt & n.d. & n.d \\
\hline \multirow[t]{20}{*}{ IV } & Fenthion $^{*}$ & 0.45 & Water source I & Diazinon & 2.81 \\
\hline & & & & Malathion & 12.20 \\
\hline & & & & Methylparathion & 1.93 \\
\hline & & & & Fenthion* & 0.29 \\
\hline & & & Water source II & Diazinon & 0.94 \\
\hline & & & & Malathion & 0.18 \\
\hline & & & & Fenthion $^{*}$ & 0.03 \\
\hline & & & Pasture & Malathion & 1.73 \\
\hline & & & & Fenthion $^{*}$ & 3.27 \\
\hline & & & Cassava & Diazinon & 3.98 \\
\hline & & & & Fenthion* & 7.29 \\
\hline & & & Cottonseed & Malathion & 9.6 \\
\hline & & & Soy & n.d. & n.d \\
\hline & & & Barley & Dimethoate & 0.02 \\
\hline & & & & Diazinon & 27.10 \\
\hline & & & & Methylparathion & 8.75 \\
\hline & & & & Malathion & 16.08 \\
\hline & & & & Fenthion $^{*}$ & 8.11 \\
\hline & & & Mineral salt & n.d. & n.d \\
\hline & & & Salt & Malathion & 1.50 \\
\hline
\end{tabular}

* Active principles detected in milk and in the animal feed; n.d. = not detected.

a controlled experiment, the results which indicate that pesticides pass readily from feed to milk, sometimes, are very hard to be reproduced and demonstrated (Indraningsih et al. 1993, Surendra et al. 2000). It can be attributed to high solubility of some of those components. Therefore, animals secrete most of these chemicals in their urine and feces (IDF 1979).

It should be pointed out that this study was not a controlled feeding experiment, and pesticide daily intake was not constant. Even this way, in four farms, the same active principle was detected in milk and feedstuff provided to lactating animals and/or in water (Table 4), suggesting the pesticides residues could have been transferred from animal feed to milk. 
Some milk samples were positive for the pesticides studied, but in foodstuff these contaminants were not detected, and the opposite was also observed. This is justified because pesticides residues in feed could have suffered environmental degradation, being below the detection limit, or the contaminated feed component was no more in the farm. Still it is possible that contamination could be from the use of ectoparasite treatment on animals.

The feed to milk transference of pesticides is influenced by quantity ingested, absorption, pesticide metabolism and excretion by animals in production. Thus, the best risk management tool is prevention of exposure, either through feed or from the environment, of the animals to these contaminants, as well as the application of a withdrawal time (Kan \& Meijer 2007).

One of the possible sources of contamination by pesticides for the dairy cattle in this study was the ingestion of contaminated feeds; therefore it is necessary to monitory the feeds and grains destined for animal consumption, but these are not the unique fonts of contamination.

The great amount of contaminated water and feed by OP and $\mathrm{CB}$ residues and their quantification in a largest part of milk samples are concerning data. Thus, monitoring of residues in feed, for animal and human consumption, is a helpful tool and its data can be reference to a vigilance system in Brazil, decreasing the risks for consumers.

\section{CONCLUSIONS}

In this investigation, milk, animal feed and water samples from dairy farms of the Agreste region of Pernambuco was found contaminated by CB and/or OP residues pesticides, and some of these residues could have been passed from animal feed to milk.

Despite the fact that a high percentage of raw milk samples were contaminated with those residues, the contamination level is lower to MRL.

\section{REFERENCES}

Araújo A.C.P., Nogueira D.P. \& Augusto L.G.S. 2000. Pesticide impact on health: A study of tomato cultivation. Revta Saúde Pública 34(3):309-313.

Brasil 2001. Instrução Normativa no 15, Diário Oficial da União, Ministério da Agricultura Pecuária e Abastecimento, Brasília.

Collins C.H., Braga G.L. \& Bonato P.S. 1997. Introdução a Métodos Cromatográficos. 7aa ed. Unicamp, Campinas.
EEC 2005. Regulation (EC) 396/2005 of the European Parliament and of the Council of 23 February 2005. Oficial Journal of the European Union, Strassbourg, France.

FAO/WHO 2006. Codex Maximum Limits for Pesticides Residues. Codex Alimentarius Commission, FAO and WHO, Rome, Italy.

Garcia de Llasera M.P. \& Bernal-Gonzalez M. 2001. Presence of carbamate pesticides in environmental waters from the northwest of Mexico: determination by liquid chromatography. Water Res. 35(8):1933-1940.

IDF 1979. International Dairy Federation Bulletin, Chemical Residues in Milk and Milk Products. I.D.F. Document.

Indraningsih McSweeney C.S. \& Ladds P.W. 1993. Residues of endosulfan in the tissue of lactating goats. Aust. Vet. J. 70(2):59-62.

Jahed Khaniki Gh R. 2007. Chemical contaminants in milk and public health concerns: A review. Int. J. Dairy Sci. 2:104-115.

Kan C.A. \& Meijer G.A.L. 2007. The risk of contamination of food with toxic substances present in animal feed. Anim. Feed Sci. Technol. 133:84-108.

Moraes E.C.F. 1991. Manual de Toxicologia Analítica. Roca, São Paulo.

Nero L.A., Mattos M.R., Beloti V., Barros M.A.F., Pontes Netto D. \& Franco B.D.G. de M. 2007. Organophosphates and carbamates in milk produced in four milk producing regions from Brazil: Occurrence and activity against Listeria monocytogenes and Salmonella spp. Ciênc. Tecnol. Aliment. 27:201-204

Nunes M.J., Camões M.F. \& Fournier J. 1997. Analysis of organophosphorus, organochlorine and pyrethroide inseticides in medical plants. Chromatographia 44:9-10.

Ortolani E.L. \& Brito L.A.B. 2001. Enfermidades causadas pelo uso inadequado de "cama de frango" na alimentação de ruminantes. Revta CFMV, Brasília, 22:41-48.

Osweiler G.D. 1998. Toxicologia Veterinária. Artes Médicas, Porto Alegre.

Pagliuca G., Serraino A., Gazzotti T., Zironi E., Borsari A. \& Rosmini R. 2006. Organophosphorus pesticides residues in Italian raw milk. J. Dairy Res. 73:340-344

Rothwell J.T., Burnett T.J., Hacket K., Chevis R. \& Lowe L.B. 2001. Residues of zeta-cypermethrin in bovine tissues and milk following pour-on and spray application. Pest Management Science 57(11):993-999.

SAEG 2007. Sistema para Análises Estatísticas. Versão 9.1. Fundação Arthur Bernardes, UFV, Viçosa.

Sankarararamakrishnan N., Sharma A.K. \& Sanghi R. 2005. Organochlorine and organophosphorous pesticide residues in ground water and surface water of Kanpur, Uttar Pradesh, Índia. Environ. International 31:11-120.

Surendra N.B., Unnikrishnan V., Gayathri V., Chitra P.S., Preeja C.N. \& Ramamurthi M.K. 2000. Organochlorine pesticide residues in animal tissues and their excretion through milk. J. Food Sci. Technol. 35(6):547548.

Tsiplakou E., Anagnostopoulos C.J., Liapis K., Haroutounian S.A. \& Zervas G. 2010. Pesticides residues in milks and feedstuff of farm animals drawn from Greece. Chemosphere 80:504-512. 